\title{
Sarah Kane's Blasted: Examining the Issue of Sexual Assault
}

\section{Shaaban Sulaiman Sadeeq}

Department of English Language, College of Education and Languages, Lebanese French University, Erbil, Kurdistan Region, Iraq shaxawansuliman4@gmail.com

\section{ARTICLE INFO}

\section{Article History:}

Received: 3/4/2021

Accepted: $17 / 5 / 2021$

Published: Summer 2021

Keywords: Sarah Kane, Sexual misconduct, war, theatrical metamorphosis, homophobia, homosexuality.

Doi:

10.25212/lfu.qzj.6.3.36

\section{Introduction}

\begin{abstract}
Sarah Kane's Blasted deals with sensitive issues that generate a lot of controversy. She demonstrates anti-feminism in the play because of the way she has shifted the audience attention away from the sexual turpitude committed against the only female character (Cate) in the play; and how she places emphasis on the sexual abuse inflicted on lan the male character. Questions that would possibly arise are: what is her insinuation? Is she trying to defend sexual violence against women? Does it mean that men have the right to rape? Why has she not taken sexual violence against the female character serious? Why is attention drawn to the male rape than the female rape? Does Kane try to portray a new view of rape? All these questions and many more could have been streaming through the viewers' mind. Notwithstanding, this paper attempts to examine the pedigree and degree of sexual misconduct in the Blasted and the reasons that make the writer draw the attention of the audience to the sexual abuse that men undergo rather than the common and popular one against the women. Thus, at the end of the play, the critical eye can make one realize that, Sarah Kane isn't an anti-feminist person but deep down in her, she cleverly defends women, presenting them as a figure with perseverance, love and strength despite all men's demonization about them; and this she reflects in Cate's character.
\end{abstract}

Theatre has gone through a lot of developments and evaluations over the years. And many writers have come up with different plays that have examined the 
metamorphosis of theatre. Thus, as time began to progress, people felt a need for social change and artistic development just as it happened during the modernist period. There was a situation when people began to yarn for new things and life. People were tired of the dogmatic way of doing things such as the period of realism. Then people decided to revolt against almost everything in order to create a new world that they hoped to see. As people experienced the two different world wars, then there was a great loss of trust in God, people, government and human goodness. Thus, modernism emerged as a new study. This was the period when people determined to take their destinies into their hands by revolting against any old establishment. This period was not circumscribed to only the development of artistic beauty but to some other things. Therefore, in the area of theatre, different innovations and establishments began to evolve. In this wise, Sarah Kane may be assumed as an experimentalist who does not only present her play for revealing the people's plight in war and sexual misconduct, but also tries to embellish some intellectual points. This study explores mainly the sexual exploitations that are more conspicuously presented in the play and also touches some other aspects such as war and the deplorable aspect of women condition during the war.

\section{Exploring Sexual issues in Blasted}

When Kane's Blasted was first performed in 1995, it was considered a footprint in modern theatre history of Great Britain; it was marked as the play which had the same representation of Bond's Saved (1965) and Romans in Britain (1980) by Howard Breton. Blasted can be categorized as the play that permits real aggression on stage and for this reason it invites strong obloquy from the society. Saunders postulates that " Sarah Kane's debut, Blasted on 12th January 1995 provides a fortuitous nexus for theatre historians"( Saunders, 2002, p. 1). Saved, reflects a group of working class young people who commit atrocity by stoning a little child to death in which the father of the child actively participates in the brutal killing of the child. Hence, Roman in Britain presents a young Celtic seer who is sexually assaulted on stage; and this time, her sexual violence situation is perpetrated by a Roman Centurion. Thus, these two issues are outrageous event in the public and audience space. This is deconstructed and revealed to the people as a way of interpreting drama through the crime 
committed against the theatre itself. Notwithstanding, the evil committed in Blasted has a similar deconstructed content in the press of England. Hence, " As playwright born in the 1970s, witnessing the devastating events of the 1990s, Kane's fears, anger and desire are well reflected in her plays" (Al-Hachami, 2020, p. 1).

Despite the comparison of these three plays, Blasted is given a quick re-examination due to the harsh criticism it had received when it was first performed. This especially happened because of the suicide she committed in the month of February, 1999; tragically, she was just twenty eight years old. Hence, Kane began to have a lot of fans in the theatre even Edward Bond is one of her supporters. He seriously encourages the quality and efforts she has put into her work. Her Blasted has become greatly accepted as one of the prominent works of the theatre and most of the theatre critics who used to destructively criticize her play now embrace and praise her.

In decades, sexual misconduct has been a tough and complicated subject which has always been the concern of the society. Most of the time, female folks have always been the victims, though there is a few number of male who are also victims of sexual violence. Notwithstanding, as several articles have been written on this issue, there hasn't been any logical solution to this problem. In Sarah Kane's Blasted, it has become an object of surprise that many chroniclers have tried in their capacity to write about the historical background of rape case. These scholars planned to write about how rape can be eradicated rather than talking about it as a subject matter. Sarah Kane's Blasted does not only reflect the motif of rape but there are other salient issues addressed in the play. The author intends to explicate the theme of war, social decadence, sexual misconduct and gender.

An important part of the play is how she symbolically presents rape in rape scenes. Ablett maintains that "The postulated movement from a symbolic to a semiotic state in Blasted is illustrated through an analysis of the changing manifestation of defilement and rape in the play" (Ablett, 2014, p. 1). The playwright reflects in different forms to depict the type of rape she is presenting in the play. As the play continues to unfold sequentially, the most ill-favoured rape is reflected through the male character, Ian. At this point this aspect might give the audience a misconception 
that the most heinous history of rape has been brought into people's view; therefore, the rapist has experienced retribution by also becoming a rape victim. This serves him right for all the evil and rape activities he has committed against women for years. In this sense, the longtime quietness over the issue of rape against women has been broken.

one could see and baffle if there is anything that makes one lose empathy for lan for being raped or one could interpret it as a symbolic way of taking a pound of flesh on all men who take violating women as a habit. The author presents rape as an involvement, and revealing gender disparities, and inequity. In this case, Zurbah postulates that "Kane represents how incidents of rape highlight, exacerbate and solidify the unevenness of power distribution between men and women in the modern world and provides a new perspective at what we might call "rape in general" (Zhurba, 2008, p. 2).

Furthermore, one will illuminate over certain questions that might arise along the line, that is: why is it that the allegorical woman is presented as a victim of rape not considering that Cate, the only female character does not appear in the scene where lan is raped? Also, the feminist critics have refused to show interest in a play that critically reflects sexual assault and principally authored by a female figure. It is considerably possible to think that Kane has decided to create a new view of sexual assault different from the way it has been viewed for years. In this sense, the old view about women being the victims of rape then changes to men being raped. On other hands, as feminists plan to eradicate the role of gender, one could interpret the play in a way that it is a developmental application of artistic beauty that represents how the major deconstruction of feminism and masculinism can be eliminated. It provides the situation in which a man is raped. Hence, Setayesh and Anushiravani explicate that "Sarah Kane, a provocative playwright, was a pioneer in "in-yer-face theatre", a movement that pushed the boundaries of conventional theater" (Setayesh and Anushiravani, 2017, p. 1).

Although, the obvious act of rape happens to lan, but looking at it from the social perspective, Cate may be seen as the victim; and this confirms the fact about the 
patriarchal establishment that sexual assault is basically about female. This campaign of sexual assault has been an issue being advocated for by many feminist writers like Mackinnon and De Lauretis who in one accord express that sexual assault is basically a female's issue. In this sense, they believe that women are mostly the victim of sexual assault while men are always the malefactors. Looking at the way Kane presents or represents rape in her play, she uses lan's body as a symbol of Cate's sexual assault; and this explains the fact that sexual assault is not an issue of today, but it is a fundamental problem with a very strong historical root. Therefore, Kane's "texts deal with themes of destructive love, sexual craving, pain, physical and psychological dimensions of cruelty, issues of distress, melancholia and death" (Biçer,2011, p. 76).

In order to examine the issue of sexual assault against women, it is very imperative to note that rape in this sense, is connected to social order on sexual assault and it has a symbolic representation both in men and women. Also, looking at the ideological intent of Sarah Kane, it is assumed that she doesn't have a strong support for feminist view, and this is represented in the way she presents her play to the audience. Kane's view about women is indifferent and this calls for a critical evaluation in which she does not give so much attention to her own gender peculiarity despite that Blasted reflects gender motif. The first ten years studies of Blasted preliminarily dealt with lan's sexual molestation, and greatly celebrated because it was seen as a way of getting rid of sexual assault in the society. "Nonetheless, despite lan's refusal to become an active denouncer of violence, Kane makes Blasted assume the humane role lan has utterly rejected throughout the play" (Peña,2009, p. 116).

But many scholars have refused to point out that intellectual interest has not been given to the part where Cate's sexual assault is not appropriately represented. In this case, the play presents the rape of a woman as a normal sexual engagement from the domiciliary and battle perspective. scholars haven't pointed out the important aspect of Cate being absent in lan's rape or in the concluding sequence of the play where he is perhaps sexually abused again.

Kane deliberately underestimates the rape committed against Cate by lan but she clearly presents lan's rape and the evil that the soldier explicates that he has 
committed and eventually rapes him. Kane tries to present to the audience that even Cate has never escaped the scene of rape from the window of the bathroom following the incidence of the bomb blast. The role she plays in the play is consistently maintained as the victim of sexual assault from the beginning till the end of the play. This reflects that sexual violence has been a pandemic that has been pervading the society for years and it requires immediate attention.

Looking at the nature of Blasted one will realize that it compels the issue of dramatic aggression, and asks for the duty of absolute aggression in the theatre space. As it has singlehandedly reflected the examples of theatre aggression in which the audience is able to feel the impact is crucially absorbing. Hence, this kind of aggression is seen as a functionality of aesthetic obstruction; and this purposefully disrupts the flow and consistency of the play. In this view violence in the theatre functions badly and the symbolic representation becomes unintelligible.

However, some other scholars have a contrary view as regards that Kane's Blasted is a distortion of aesthetic values of the theatre; they claim that instead of seeing it from the distortion angle, it could be viewed as another way of adding more aesthetic value to the theatre. And this is significantly surrounded by the contemporary tragic political situation of the theatre in this modern time. Thus, Blasted tries to represent what Hagel refers to as the concrete; and as this aesthetic value begins to evolve it reflects ideology of chronicle.

As an artistic work, the play reflects the conscious circumstance of chronicle as a redemptive possibility, still it reflects the historical consciousness as something that is not realizable because history has no end and it is not possible to attain total outand-out. Hence, one can identify the reflection of history in the play if one regards it as a play with the genre of modern tragedy. The setting of Blasted is in a small luxurious hotel room in the city of Leeds-and it reflects a great aesthetic value of modern theatre. It is so reflective to the extent that as the play progresses the room practically bursts because of the duress. But prior to this practical burst, the two characters are introduced, lan and Cate; they come into the hotel room and go ahead to play due to the worsening fragments of the inadequate and broken relationship. 
The play starts by giving an impression that there is realism, with a shut room, showing the interior space, the psychological situation and sexual affair. It is later discovered that Cate is twenty-one years old; she is a middle class from London, and also a vegetarian. She appears innocent, and unworldly. Her previous boyfriend lan is revealed to be cunning, racially biased, with a propensity of homophobia.

He is forty-five, and a journalist who is always moving around with gun and he is a cancer patient. It is seen that lan has told Cate to meet him in the hotel in order to solve the problem of their love affair or to persuade her to indulge in sexual relationship with her or probably planning to do the two; and Cate decides to come because she is sympathetic about his bad health condition. The first fainting that Cate displays is to understand the motif of the play; the issue of death and the people's reaction to it. Cate faints when the play just starts, and then she wakes and bursts into a hysterical laughter, uttering words of caution to an unidentified lady, she keeps her eyes closed and gradually comes back to her usual sense. Because of this attitude displayed by Cate, lan is shocked because he has never experienced such a thing before.

Blasted seriously opens up lan's life practically and figuratively; and looking at this situation from sexual assault angle, the play is in line with the convention of putting sexual assault into a forgotten situation. However, the issue of sexual assault in the play draws a serious concern, and it is treated ostensibly. Furthermore, many critics talk about the cruel activities that occurs and the sexual violence is one of the principal components to be indicated.

more attention is drawn to the cruel and brutal aggression inflicted on lan but surprisingly, the sexual assaults that Cate goes through on several occasions is always ignored. Definitely one will be surprised why it is so. The presumption about Cate's neglected ordeal is that it is a reflection of what is going to happen on stage subsequently. It is very essential to pay attention to how she has been sexually abused at the concluding sequences of the play and also the duty of Cate in how lan also becomes the victim of sexual violence. Thus, regarding this situation, Solga (2007) becomes the first critic to maintain that the sexual assault inflicted on Cate by lan 


\section{QALAAI ZANISTSCIENTIFIC JOURNAL \\ A Scientific Quarterly Refereed Journal Issued by Lebanese French University - Erbil, Kurdistan, Iraq \\ Vol. (6), No (3), Summer 2021 \\ ISSN 2518-6566 (Online) - ISSN 2518-6558 (Print)}

should be given serious concern and study. The main question that ensues is that why has the play that reflects sexual violence refused to be concerned about the sexual assault that Cate goes through. Factually, it has been seriously ignored to the extent that even the author never gives it any serious attention.

Especially, in the course of the cruel activities, it is marvelous to realize that the author deliberately shifts the attention of the audience away from the sexual abuse that Cate goes through by using poetic metaphor; the flower which has been shattered away and messed around the room. Only a metaphorical representation of Cate's ordeal is presented by the author. Does Cate not deserve audience's sympathy? Does she need to be presented as a sexually abused lady but without any comment made about that cruelty? Does it mean that she deserves such treatment without being spoken for? These rhetorical questions might require more practical answers in subsequent studies. Although, Solga (2007) hasn't mentioned gender issue in her work but it is an eye-opening component for this study. Hence, Rebecca explains that 'Sarah Kane uses cruelty in her plays Blasted and Cleansed to shock the audience out of their indifference, which will then allow Kane to subvert gender norms, through performed acts on stage" (Rebecca, 2008, p. 3).

Together with Carney and Wixson, Solga further maintains that the decision of not giving much concern to Cate's sexual assault is deliberately done. In this content, Blasted is an expanded statement about the chronicle of the cultural denial of sexual assault. Therefore, performing the allegorical content of sexual violence is an attempt to hide something. Thus, the analysis and interpretation that Solga gives to the sexual violence against Cate is a critical point that requires more studies.

it is a thing of surprise that Solga has refused to inculcate the sexual assault that Cate goes through in the concluding part of her Work. As the first sexual violence happens in the period of harmony, all other sexual assaults that eventually occur are within the occasion of war and this aggravates the main concept of rape. The battle places emphasis on the efficacy of power to exhibit sexual assault by the body of the rapist in army uniform holding a gun; this represents total hegemony of the powerful over the commoners. 


\section{QALAAI ZANISTSCIENTIFIC JOURNAL \\ A Scientific Quarterly Refereed Journal Issued by Lebanese French University - Erbil, Kurdistan, Iraq \\ Vol. (6), No (3), Summer 2021 \\ ISSN 2518-6566 (Online) - ISSN 2518-6558 (Print)}

According to Kane, she describes Blasted as "eventually logical merger of themes that are at first glance utterly distinct, gendered violence and civil war, brought about by news footage from the Bosnian conflict" (Kane; cited in Zhurba,2008). Looking at this situation, one might presume that this act of sexual violence in the camp is as a result of a norm. Thus, it is efficacious to consider the fact that, sexual violence has been often regarded as bad but it has become very peculiar to the convention of war. Perhaps Kane is not used to the cultural norm of the Yugoslav but Blasted is seen to have given some summary of the common norm practiced against women during war. Wixson postulates that "Kane seeks to dismantle the old psycho-geographical dramaturgy and construct onstage a new model of place and identity from the devastation" (Wixson, 2005, p. 75).

The cultural characteristics of the Yugoslav territory shows that they have so much tolerance for sexual assault during war, for this reason, perpetrating sexual violence is not taken as a serious crime. Ugresic (1998) proposes that war is always the stimulating factor of any kind of violence inflicted on women by men. It is not appropriate to have a final conclusion based on a single person, but Ugresic gives this point of view based on the cultural examination about Yugoslavia. Therefore, Kane Blasted reflects the gender function about the current man and woman.

As Ugresic maintains further, the role that the female folks played in Balkan during the war was that they lost their family, husbands, and offspring; and got sexually violated. Therefore, defining women is permanently circumscribed to establishing a family and being positioned for sexual violation. Being extremely obedient is as a result of sexual and masculine violence against women in the war territory. Therefore, Blasted explicates the same event and this is greatly reflected in the interpretation of the play.

Thus, looking at the circumstance of the play, Kane attempts to omit sexual disparity through her personality and the characters she has created; and this is a very cogent reason for the feminist critics to give their views about her play because there is an attempt to eliminate both female and male images in the play. 


\section{QALAAI ZANISTSCIENTIFIC JOURNAL \\ A Scientific Quarterly Refereed Journal Issued by Lebanese French University - Erbil, Kurdistan, Iraq \\ Vol. (6), No (3), Summer 2021 \\ ISSN 2518-6566 (Online) - ISSN 2518-6558 (Print)}

It is therefore surprising that the feminist critics have not given their critical views about a play that projects a woman being raped. Although, there has been a common conclusion regarding the lan's rape that it is a way of taking a revenge on men for how they have been inflicting sexual trauma on women-but sincerely, this is not absolutely convincing from the feminist point of view. Hence, in the play, as Cate absconds from the hotel, the soldiers foresee the sexual abuse she will face irrespective of what she tries to do. According to Aston (2003), many male scholars attempt to attribute feminist objective to the aesthetic values created by Kane. Innes (2002) posits that Kane and Churchill establish a great progression in a drama that reflects feminism. Saunders (2002) points out that Kane's drama creates a new way of breaking the rules of women's plays that always speak to support women. But rather than taking side of women, Kane presents the opposite in which the suffering of the only female character in the play is overlooked. Looking at this aspect, and relate the play with the playwright's gender, and coupled with the critics' opinions, it is so clear that one cannot identify the playwright's tone, whether as a man or woman.

she refuses to identify herself as a specific gender, instead, she separates herself from her personality, and she communicates as an unbiased person who doesn't want to give priority to any of the either genders so, she becomes neutral. The writer's view proposes that people in general are expected to challenge system at which rape is measured. As Kane refuses to support women it might be considered that (in Kane's view) sexual abuse is a common phenomenon which is not seen as a big deal. Thus, one needs to reason that this tradition can be disputed. Blasted therefore reflects the norm of quieting sexual violence because of the dynamic reflection of situations of sexual violence that takes place in the play; and this can be seen in the play as lan's rape is presented while Cate's rape is not taken into consideration.

Cate goes through the odious process of sexual assault in a very aggressive manner; even in the absence of war in Leeds. She tries to defend herself, using a gun prior to the blast that takes place and the intrusion of the soldier. As the soldier enters, the cruelties are seen as normal. Kane disrupts the space between harmony and battle 
looking at the attitude towards female figures. Giving a close explication of the characters and the rape scenes, it reveals the gender issues and the aesthetic value of representing gender in the society. Wixson maintains that Kane "attempts to represent the political, ethical, and existential unconscious while avoiding euphemism through abstract" (Wixson, 2005, p. 76).

\section{The Sufferers and the Assailants in Blasted}

In evaluating the roles of the dramatis personae in Blasted, it becomes a bit confusing to differentiate who suffers and who inflicts the suffering. Cate appears to be the sufferer: there are good factors that can make one ascribe suffering to her; she is epileptic, has no job, backward, she continues to suck her thumb from the starting point of the paly till the last sequence, and she is sexually molested by lan. Something about her is that, she is badly treated by lan, yet, she is so concerned about him and for this reason she keeps on coming back to him. She also endures all the unfavorable treatment she has been experiencing. One could see her as the one who suffers so much among the characters despite that the author has refused to pay attention to such heinous situation. Kane forms lan's character that frequently swings from violence to fright, and from affection to hostility. he has always been insulting Cate, he then tries to utter some words that his plan is to look after Cate and stop her from getting hurt.

lan continues to molest her as he has been molesting other females generally. He then harshly talks to Cate, exercises his dominant male power over her and makes himself look superior in the eyes of others. He behaves as if he knows everything and possesses the ability to describe the truth. He treats Caste as though her level of intellect is very low, and so he believes that she is unemployable. Furthermore, Ian expresses his callous disposition when he talks about a British tourist killed by a deadly murderer; he comments that the tourist is supposed to be blamed because she is the one who permits her legs to be put apart, therefore, her case doesn't deserve any important attention or discussion.

Now one could see the masculine representation being reflected in the injured nature of lan character as he is being seen as a hero prior to the time he is cruelly penalized. 
Hence, one can notice a kind of transformation that the two charters experience towards the last sequence of the play in which lan gets transformed from homophobic into a violated person. The soldier, can be seen as another sufferer despite his cruel behavior; although his behavior is as a result of trying to avenge on behalf of the girl he loves. They buggered her, cut her throat, hacked her ears and nose off, nailed them to the front of the door and ate her eyes. He laments and pours out his wounded heart as he is raping lan. First of all, when one thinks about lan's atrocities against Cate, it is painful, but as the soldier comes in and explains different kinds of cruel activities he has committed, Kane makes us see lan as a little boy in terms of cruel act. Hence, the soldier applies his war tactics into sexual abuse and the absolute control of man who possesses a gun over an allegorical woman.

\section{Conclusion}

Kane never uses her Blasted to encourage social discrimination against any of the two genders, but she tends to reveal some crucial issues though may not be accepted by many critics, that is, males are also victims of sexual abuse. It has been a long-time issue; one needs to ask if only the females are the victims of sexual abuse. Although the character of Ian is not presented with moral values, the author reveals the inordinate passion of a man who consistently molests a young lady that is much younger than him; but one could see very clearly how he also eventually becomes a victim of the same thing he has done to others. Ian is homophobic, but one could see that he eventually falls into what he fears most. Can one call it a retributive justice? Can one say lan is paid back with the evil he has inflicted on others? This could serve as another topic for further studies. Therefore, as Kane presents the play, she reflects the decadence of the society and the inadequacy of social order in which many things happen without appropriate structure. Therefore, the issue of sexual molestation as reflected in this study hasn't started today; and the truth is that men are also sexually abused but hasn't been given any serious attention. To be sincere, the problem that females have as victims of sexual abuse is also the same with the male. However, there hasn't been a generic assumption that men don't experience rape, this belief is erroneous and to have a balanced judgment, both females and males fall victim of sexual violence. In this sense, the recommendation is that researches that reflect 
male sexual victimization should be conducted and this could serve as an eye-opener to how some male figures are victims of this unfortunate phenomenon.

\section{References}

Ahmet Gökhan Biçer(2011) Sarah Kane's Postdramatic Strategies In Blasted. Uluslararası Sosyal Aratırmalar Dergisi The Journal of International Social Research Cilt: 4 Sayı: 17 Volume: 4 Issue: 17 Bahar.

Aston, Elaine.(2003) Feminist views on the English stage women playwrights, 1990- 2000. New York : Cambridge University Press.

Baines, Barbara J.(2005). Effacing Rape in Early Modern Representation. ELH 65.14. Dictionary of Literary Biography: British and Irish dramatists since World War II. Ed. John Bull. Detroit: Thomson Gale.

Brannigan, John.(2003). Orwell to the present: literature in England, 1945-2000. Houndmills, Basingstoke, Hampshire; New York: Palgrave Macmillan,

Emig, Rainer.(2007) Blasting Jane: Jane Eyre As an Intertext of Sarah Kane's Blasted. A Breath of Fresh Eyre: Intertextual and Intermedial Reworkings of Jane Eyre. Eds. Margarete Rubij and Elke Mettinger-Schartmann. Amsterdam, New York: Rodopi.

Higgins, Lynn and Brenda, Silver(1991). Introduction: Rereading Rape. Rape and Representation. Eds. Lynn A. Higgins and Brenda R. Silver. New York: Columbia University Press.

Innes, Cristopher.(2002). Modern British Drama: The Twentieth Century. Cambridge: Cambridge University Press, 2002. "Sarah Kane (1971-1999): the poetry of madness in violent dreams.

Langridge, Natasha and Stephenson, Heidi.(1997). Rage and Reason: Women Playwrights on Playwriting. London: Methuen, . Includes an interview with Sarah Kane.

Lauretis, Teresa.(1989)The Violence of Rhetoric: Considerations on Representation 35 and Gender. The Violence of Representation: Literature and the History of Violence. Ed. Nancy Armstrong and Leonard Tennenhouse. London and New.

Rebecca L. Dluback.(2008) Sarah Kane 's Cruelty: Subversive Performance and Gender Cleveland. State University. ETD Archive 2008 Cleveland State University. 
Sara, Setayesh and Alireza Anushiravani(2017).The Grotesque Image of the Body in Sarah Kane's Blasted: A Bakhtinian Reading. Conference: 2nd International Conference on Literature and Linguistics, Iran, Tehran.

Sarah, Ablett(2014) Approaching Abjection in Sarah Kane's Blasted. A Journal of the Performing ArtsVolume 1 - Issue 1

Zhurba, Dina.(2008) The endangered representation of sexual violence in Sarah Kane 's Blasted. University of Richmond UR Scholarship Repository Master's Theses Student Research

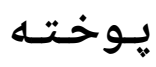

شانوّيى Blasted ى نوسهرى بهريتانى سارا كهين، باسى جهند كيشهيهكى ههستيار دهكات كه زوّر

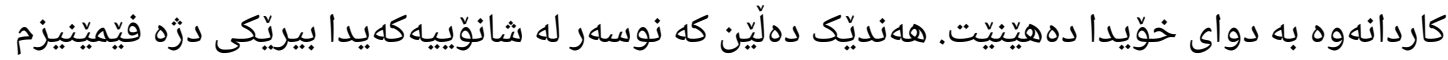

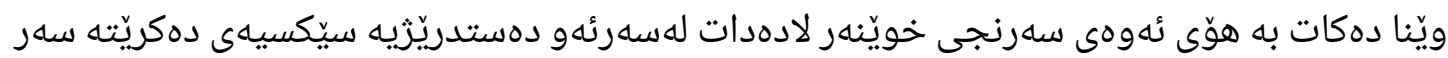

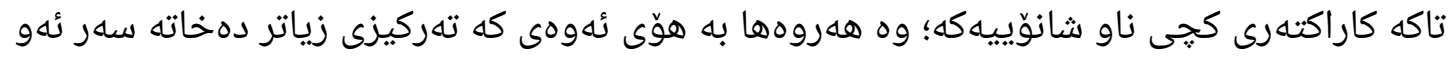

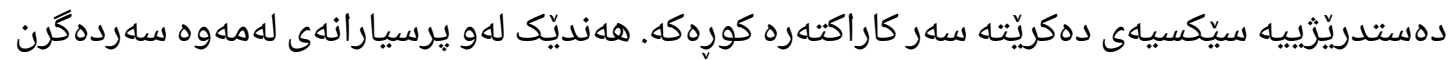
ئهمانهن: ئايا مهبهستى نوسهر جيه لهمه؟ ئايا نوسهر دهيهويّت به كهم تهماشاى دهستدريّزئى بوّ سهر

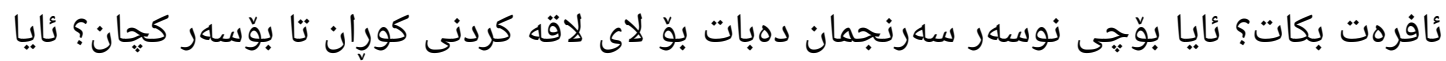

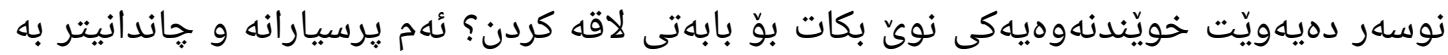

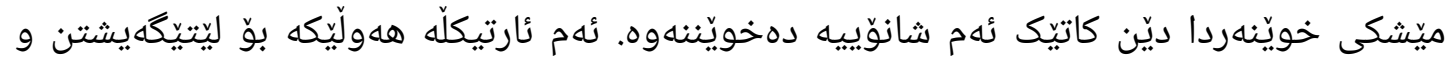

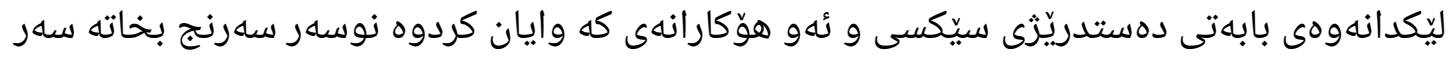

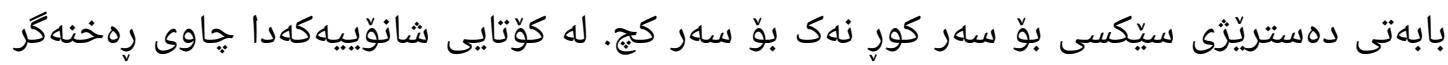

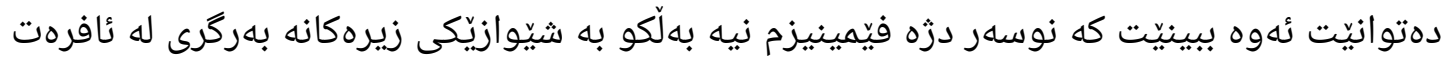

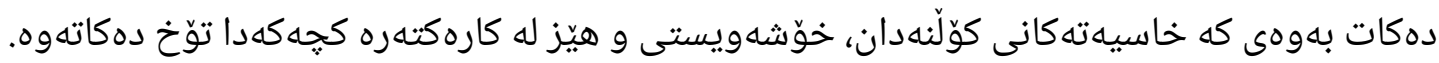


هناك تعريفات متنو عة من قبل المؤرخين و الباحثين لمفهوم (ما بعد الحداثة) لكن الهدف ليس تعريف هذا المفهوم

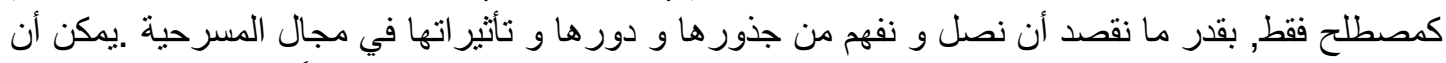

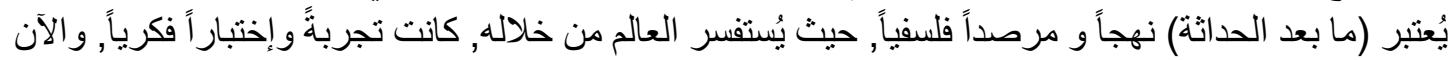

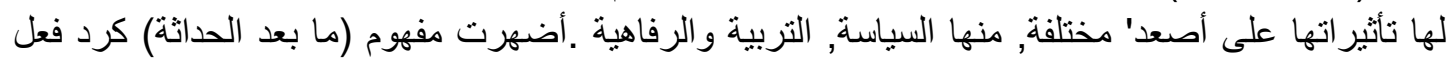

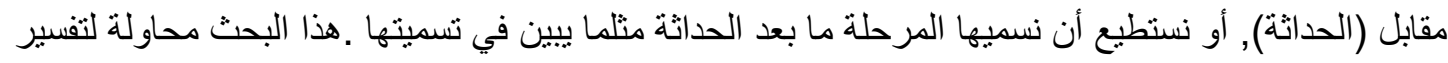

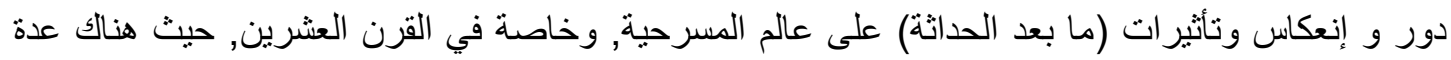

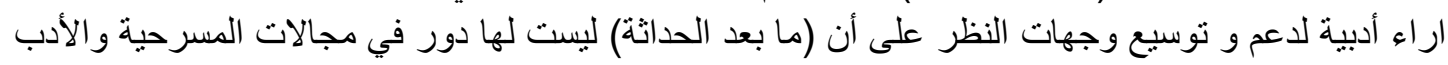
و الفنون فقط, وإنما يمتد وجهات النظر وحو حولها الى المجالات الأخرى أيضاً. 